\title{
BRYOPHYTES OF ST. HELENA, SOUTH ATLANTIC OCEAN. 7. CYLINDROCOLEA (JUNGERMANNIALES, CEPHALOZIELLACEAE): C. SANCTAE-HELENAE M. WIGGINTON SP. NOV.
}

\author{
MARTIN J. WIGGINTON
}

\begin{abstract}
A new species of Cylindrocolea R. M. Schust. from St. Helena, C. sanctae-helenae M. Wigginton, sp. nov. is described and illustrated. This is the first report of the family Cephaloziellaceae from the island.
\end{abstract}

Key words: Cephaloziellaceae, Cylindrocolea, liverwort, St. Helena, taxonomy

Martin J. Wigginton, 36, Big Green, Warmington, Peterborough, PE86TU, United Kingdom; e-mail: m.j.wigginton@btinternet.com

\section{INTRODUCTION}

Cylindrocolea R. M. Schust., a small genus of the Cephaloziellaceae, has a mostly tropical and warm temperate distribution in North and South America, Africa and south and east Asia. About 18 species are currently recognised (including the species described in this paper), most of which are known from few collections/locations or, in some cases, only one.

During a bryological survey from 15 October to 19 November 2005, the author made eleven collections of Cylindrocolea from a range of substrates (trees and shrubs, rotting logs, roots, rock and soil) in shaded habitats at midto high altitudes on St. Helena, these being the first records of the genus and, together with two or three as yet unidentified species of Cephaloziella, also of the cosmopolitan family Cephaloziellaceae from the island. The collections of Cylindrocolea could not be matched to a known species and are accordingly described under a new name.

The background to the 2005 survey and a brief description of the island of St. Helena is given in Wigginton (2006), and details of the physical environment, history, habitats and biota of St. Helena are given in Ashmole and Ashmole (2000).

\section{SPECIES DESCRIPTION AND HABITATS}

Cylindrocolea sanctae-helenae M. Wigginton, sp. nov.

Figs 1-5

TYPE: ST. HELENA, Blue Hill Village, in small valley $\mathrm{E}$ of road: on shaded, moist upper surfaces of horizontal rotting tree trunk, in Podocarpus elongata - Agave community in valley bottom, $525 \mathrm{~m}$., 30L/ $\mathrm{TH} / 055314,5^{\circ} 45^{\prime} \mathrm{W} 15^{\circ} 58^{\prime} \mathrm{S}, 23$ October 2005 , Wigginton 05/191 (HOLOTYPE: E).

Plants small, variable, mid- to deep olivegreen, pale green and very slender in deep shade; slender forms minute. Robust leafy shoots 400-600 (-700) $\mu \mathrm{m}$ wide, slender shoots (200)300-400 $\mu \mathrm{m}$ wide, creeping, prostrate, in thin patches of loosely or intricately entwined stems. Branching frequent, terminal Frullania-type and ventral-intercalary (no lateral-intercalary branching observed); male and female branches frequent, ventral-intercalary. Stems to $20 \mathrm{~mm}$ long, $50-100 \mu \mathrm{m}$ in diameter, epidermal cells slightly convex, rectangular in surface view, 10-22 $\mu \mathrm{m}$ wide $\times(15-) 20-50 \mu \mathrm{m}$ long (mostly $1.8-3.1 \times$ as long as wide), walls thin or very slightly and evenly thickened, trigones lacking. Rhizoids short, hyaline, sparse, mostly at or near base of ventral branches. Leaves flat, \pm oblong or oblong-obovate, approximate to 


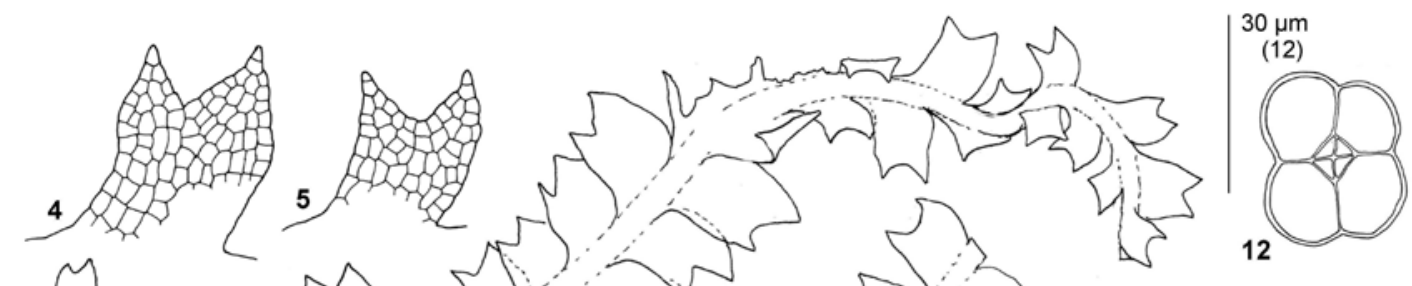

\section{som 305}

Lis

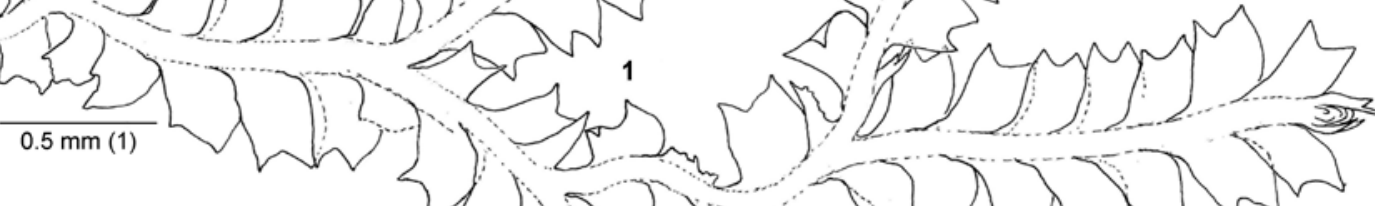
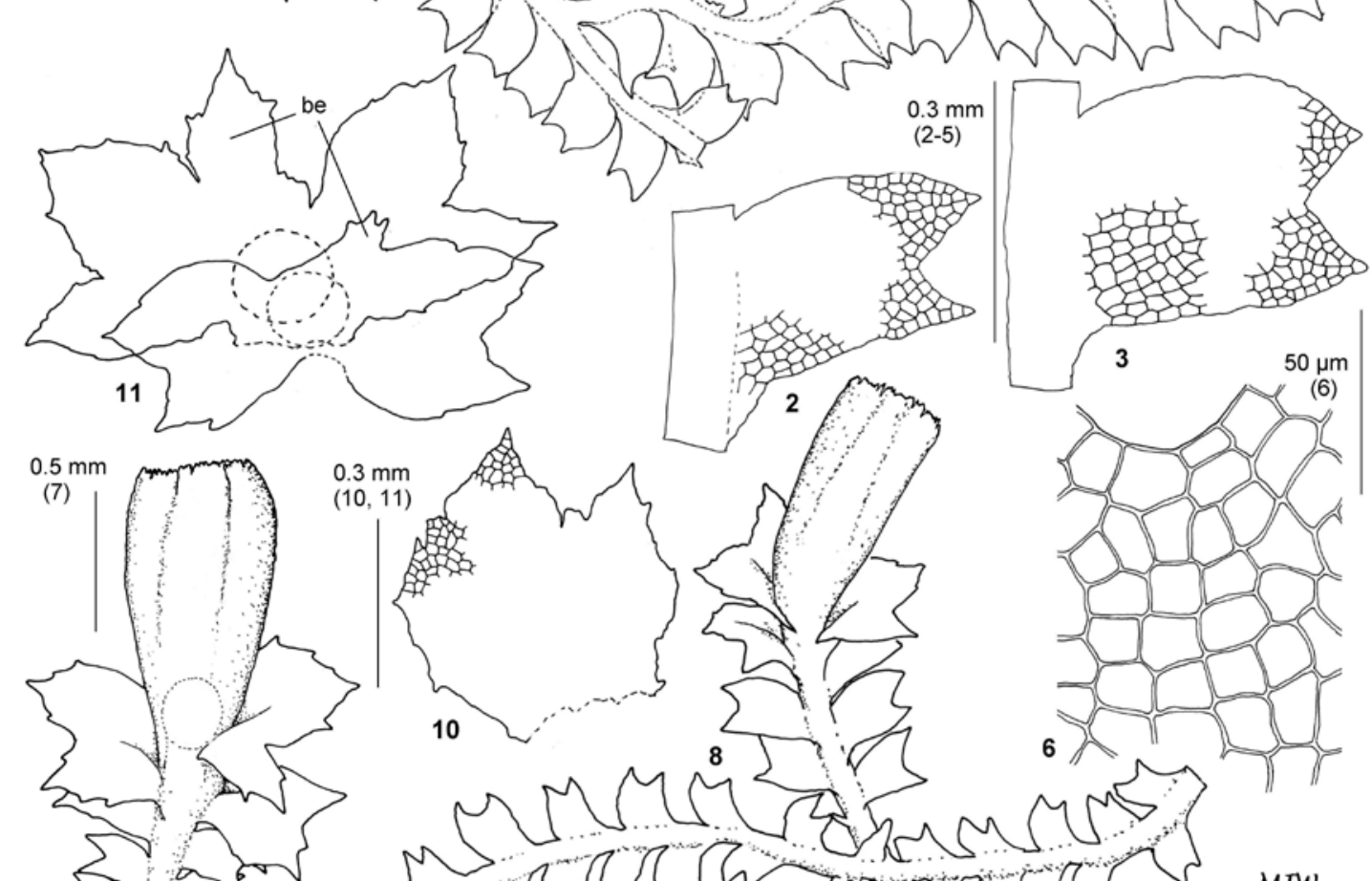
slightly overlapping on strong shoots (at most up to 1.5 leaf widths apart), distant on slender shoots (1.3-4.0 leaf-widths apart), almost longitudinally inserted on the stem, patent-spreading, longer than wide, often slightly narrowed towards the base and widest in mid-leaf, margins entire, very slightly crenulate, antical margin moderately to strongly decurrent, leaves on strong shoots 250-350 $\mu \mathrm{m}$ long $\times 200-270 \mu \mathrm{m}$ wide (at widest point), and to 15-20 cells wide at widest point, $0.25-0.4$-bilobed (usually slender shoots with more widely spaced leaves present among more robust shoots); lobes sub-equal, broadly triangular, acute, in large leaves up to 7-10 cells wide at base, apex ending in 1 cell or 2 uniseriate cells, sinus between the lobes acute to rounded; leaves on slender shoots more triangular in shape, $150-230 \mu \mathrm{m}$ long $\times 100-130 \mu \mathrm{m}$ wide, the lobes 3-5 cells wide at base, lanceolate, often divergent. Leaf cells variable in shape and size (sub-rectangular to irregularly pentagonal or hexagonal), thin-walled, trigones lacking or very small and inconspicuous, in mid-leaf (12-)1525(-30) $\mu \mathrm{m}$ long $\times(10-) 12-23(-28) \mu \mathrm{m}$ wide, cells in lobes usually smaller. Cuticle smooth. Oil bodies recorded only in the type material: 8-14 per cell, rather large, irregularly rounded, finely granulose (Fig. 3). Underleaves not observed.

Autoicous, gametoecia abundant. Androecia terminal or on short ventral-intercalary branches from main axis, often arising near gynoecial branches, rarely arising from a gynoecial branch (Fig. 2.3), of 3-9 pairs of bracts and a few leaves at base of branch; bracts widely spreading or ascendingspreading, complicate, deeply bilobed, about as wide as long, 130-200(-250) $\mu \mathrm{m}$ long $\times 140-200 \mu \mathrm{m}$ wide, one margin sometimes with a blunt tooth, ca 0.3-0.4-bilobed (to 0.8-bilobed in slender forms), the sinus sharply acute, lobes \pm triangular, unequal in size, apex acute or apiculate, ending in 1 cell or 2 uniseriate cells; antheridia 1 per bract, $38-55 \mu \mathrm{m}$ in diameter; androecia very slender and spicate in slender forms. Gynoecia almost always single on short ventral-intercalary branches, or sometimes terminal on long leafy shoots, but occasionally a secondary fertile branch develops, which quickly produces a gynoecium (Fig. 2.3), usually with 1-3 subgynoecial bract-like leaves and with 1-2 small leaves below (rarely with up to 5 pairs of bractlike leaves below the gynoecium); female bracts squarrose-recurved to suberect, in mature gynoecia (250-)350-510 $\mu \mathrm{m}$ long $\times(175-) 300-450 \mu \mathrm{m}$ wide (when flattened), bilobed to $0.3-0.4(-0.5)$ (rarely an additional, narrow, lanceolate lobe at base of bract), sinus wide (sometimes more than $90^{\circ}$ in the flattened bract) to acute in slender forms, lobes broadly triangular, usually unequal, up to 18 cells wide at base of larger lobe, apex acute, ending in 1 cell or 2 uniseriate cells, margins usually dentate with many teeth (but weakly dentate or entire in slender forms), marginal cells flat to slightly crenulate, bract cells variable in shape (quadrate to sub-rectangular to irregularly pentagonal or hexagonal), thin-walled, trigones lacking, $(11-) 15 \times 13 \mu \mathrm{m}$ to $27 \times 15 \mu \mathrm{m}$ at mid-base of lobe, marginal cells small $(11 \times 8 \mu \mathrm{m})$; bracteole ovate to broadly lanceolate, variable, longly or shortly connate with one or both bracts, 200-300 $\mu \mathrm{m}$ long $\times(90-) 150-210 \mu \mathrm{m}$ wide, either undivided or bilobed to 0.5 (sometimes one lobe of a bilobed leaf is truncated), lobe apex/apices acute, usually ending in a single elongate cell or 2 uniseriate cells; sinus rounded or acute, margins slightly crenulate, entire to sparingly dentate; depauperate bracteole also observed (Fig. 1.11); cells similar in shape and size to bract cells. Perianths variable in size and shape, broadly or narrowly cylindrical to obconical-cylindrical, (0.65-)0.90-1.20 mm long at maturity, slightly constricted to the mouth, strongly tri-plicate in the distal $0.25-0.50$ when mature, 'keels' broad, perianth mouth becoming fimbriate or laciniate-dentate (often appearing

Fig. 1. Cylindrocolea sanctae-helenae M. Wigginton, sp. nov. (robust form). 1 - vegetative shoot, $2 \& 3-$ leaves from robust shoot, 4 \& 5 - leaves from weaker shoot, 6 - leaf cells from sinus to mid-leaf, 7 - branch with mature perianth, 8 - shoot in dorsal view, with gynoecial branch, 9 - shoot in ventral view, with two gynoecial branches with immature perianths, one androecial branch and a terminal androecium ( $\star$ denotes the continuation of the stem), 10 - female bract, 11 - female bracts and connate bracteoles (be), 12 - transverse section of seta, 13 \& 14 - cells at perianth mouth. 1-14 - St. Helena, Wigginton 05/191 (holotype). 


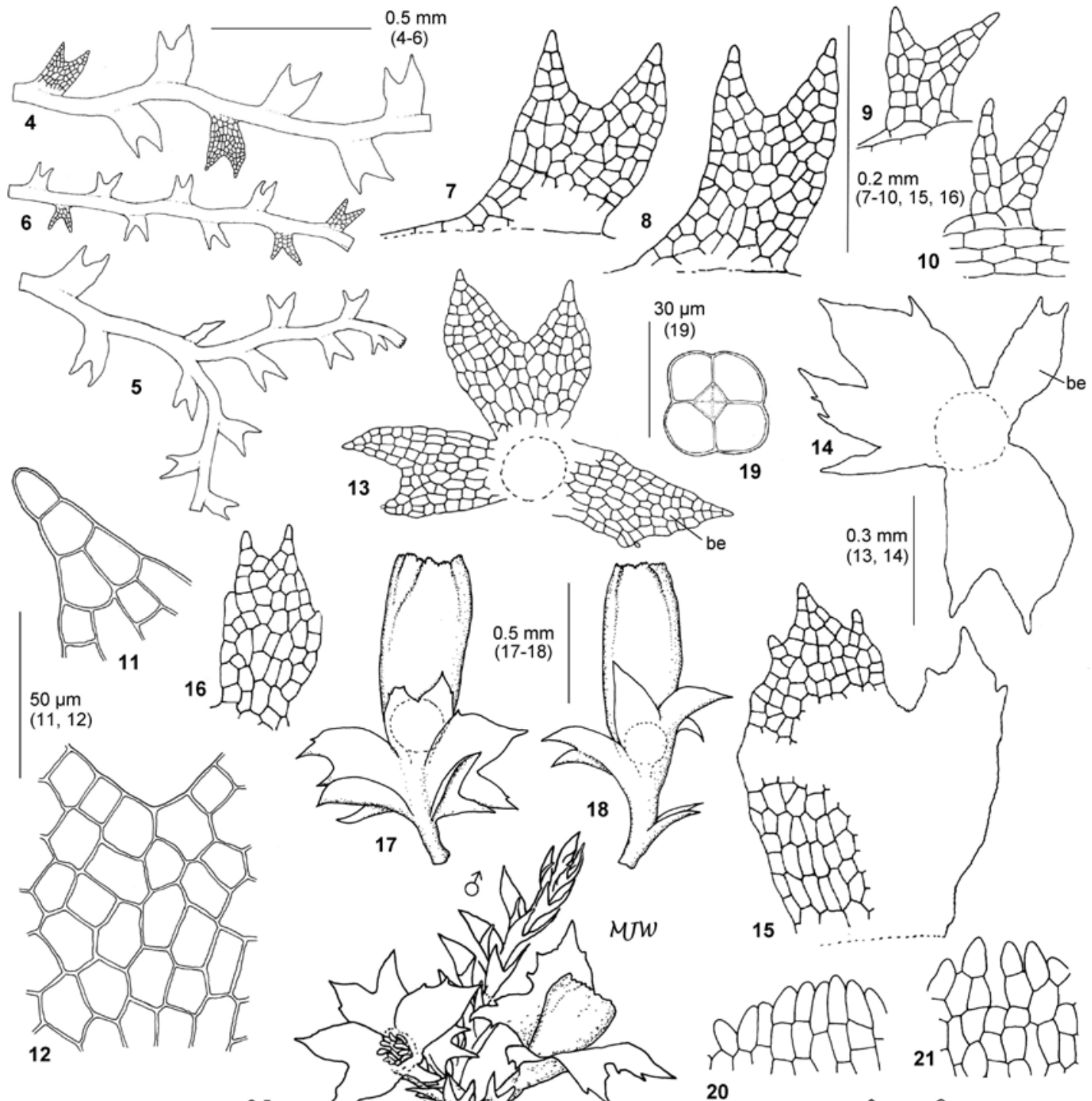

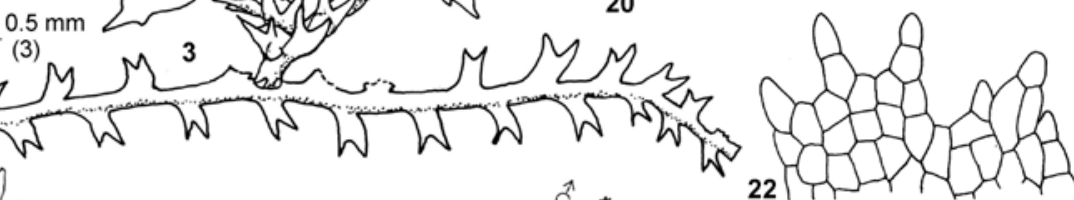
Wwin (20) 


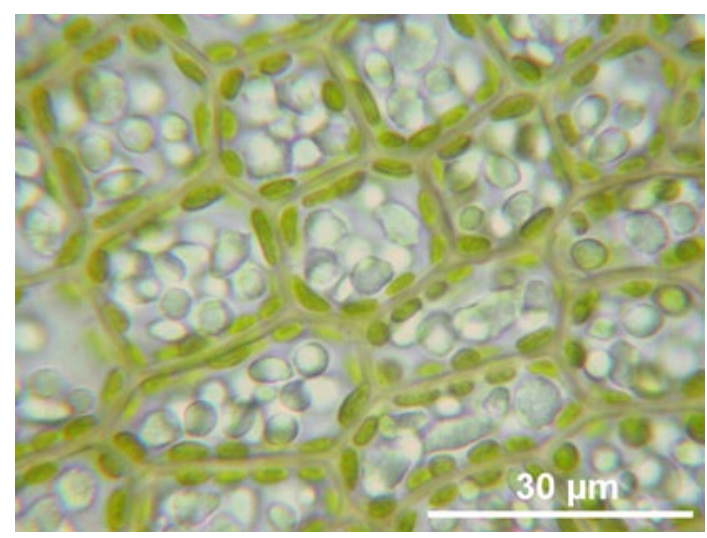

Fig. 3. Cylindrocolea sanctae-helenae M. Wigginton, sp. nov. Oil bodies and chloroplasts in mid-leaf cells. St. Helena: Wigginton 05/191 (holotype).

ragged) at maturity, the terminal cells becoming ovate (i.e. narrowed distally to a broad or narrow point), (9-)11-21 $\mu \mathrm{m}$ long $\times 8-12 \mu \mathrm{m}$ wide $(1.2-2.3$ $\times$ as long as wide), free for $0.3-1.0$ their length. Seta of $4+4$ cells (Cephaloziella-type). Capsule broadly elliptical, up to $400 \mu \mathrm{m}$ long at maturity. Elaters purple, $(75-) 100-200 \mu \mathrm{m}$ long $\times 7.5-9.0 \mu \mathrm{m}$ at the centre and tapering to the apices, $5.0-7.5 \mu \mathrm{m}$ wide at centre, bispiral, the strands 1-2 $\mu$ m wide. Spores pale brown, nearly spherical, $11-15 \mu \mathrm{m}$ in diameter (very occasionally larger and broadly ovoid), exine very finely verruculose; spore cell often with some divisions before dehiscence of capsule.

HABITATS. In moist, shaded to very deeply shaded locations, on rotting wood, on the petioles and leaf laminae of the native tree fern Dicksonia arborescens, on roots and soil, and on rock.

\section{DISCUSSION}

The St. Helena plants are very variable in form, slender ones being remarkably dissimilar in general appearance to the more robust ones (Figs 1,
$2,4)$. In particular, slender plants from some populations on the petioles and laminae of tree ferns from deeply-shaded places in native habitats at high altitudes were very different in appearance to many plants from more open habitats at lower altitudes. Because of this, it seemed at first that two distinct taxa were represented. However, slender forms were sometimes found at mid-altitude sites growing with or close to more typical forms. For example, collection 05/469B from Boer Cemetery contains mostly slender plants that very closely resemble those growing on tree ferns at high altitude. Apart from size and colour, there was little to differentiate the slender, the intermediate-sized and the more robust forms, and it was considered, therefore, that we have to hand a single, very variable species encompassing a range of phenotypes. Some populations, e.g. from Blue Hill (05/189A, $05 / 191$ ), contained only robust forms.

The study of the genus Cylindrocolea is considerably hampered by the paucity of material for study, so that the range of infraspecific variation and the taxonomic limits of most species are not fully understood. The need for more and copious collections of Cylindrocolea was remarked upon by Jones (1960), but in the fifty years since then, rather few collections have been made worldwide. However, the St. Helena taxon is readily distinguished from almost all the other described species of Cylindrocolea by the fimbriate- or laciniate-dentate perianth mouth with ovate terminal cells. The only species that has been described with similar terminal cells and laciniate perianth mouth appears to be $C$. obtusifolia Fulford, a species known from the nineteenth century type from Rio de Janeiro and a few recent collections from western Brazil (Fulford 1976; Vital \& Visnadi 1994). According to her drawings (Fulford 1976, Plate 109, Figs $3 \mathrm{~d}, 3 \mathrm{e})$, the perianth mouth and ovate cells strongly resemble those of $C$. sanctae-helenae, but Figs 3a,

Fig. 2. Cylindrocolea sanctae-helenae M. Wigginton, sp. nov. (slender form). 1 \& 2: shoots with androecial and gynoecial branches, 3 - part of shoot in dorsal view, with a fertile branch comprising one androecium and two gynoecial branches, one with an immature perianth, 4-6 - parts of vegetative shoots, $7 \& 8$ - leaves, $9 \& 10$ - leaves from weak shoot, $11 \&$ apical cells of leaf lobe, 12 - leaf cells from sinus to mid-leaf, 13 \& 14 - 'rosettes' of two female bracts and one (connate) bracteole (be), 15 - female bract, 16 - bracteole, 17 - gynoecium, with bilobed bracteole, 18 - gynoecium with entire bracteole, 19 - transverse section of seta. 20-23 - cells at perianth mouth. 1-23: St. Helena, Wigginton 05/335. 

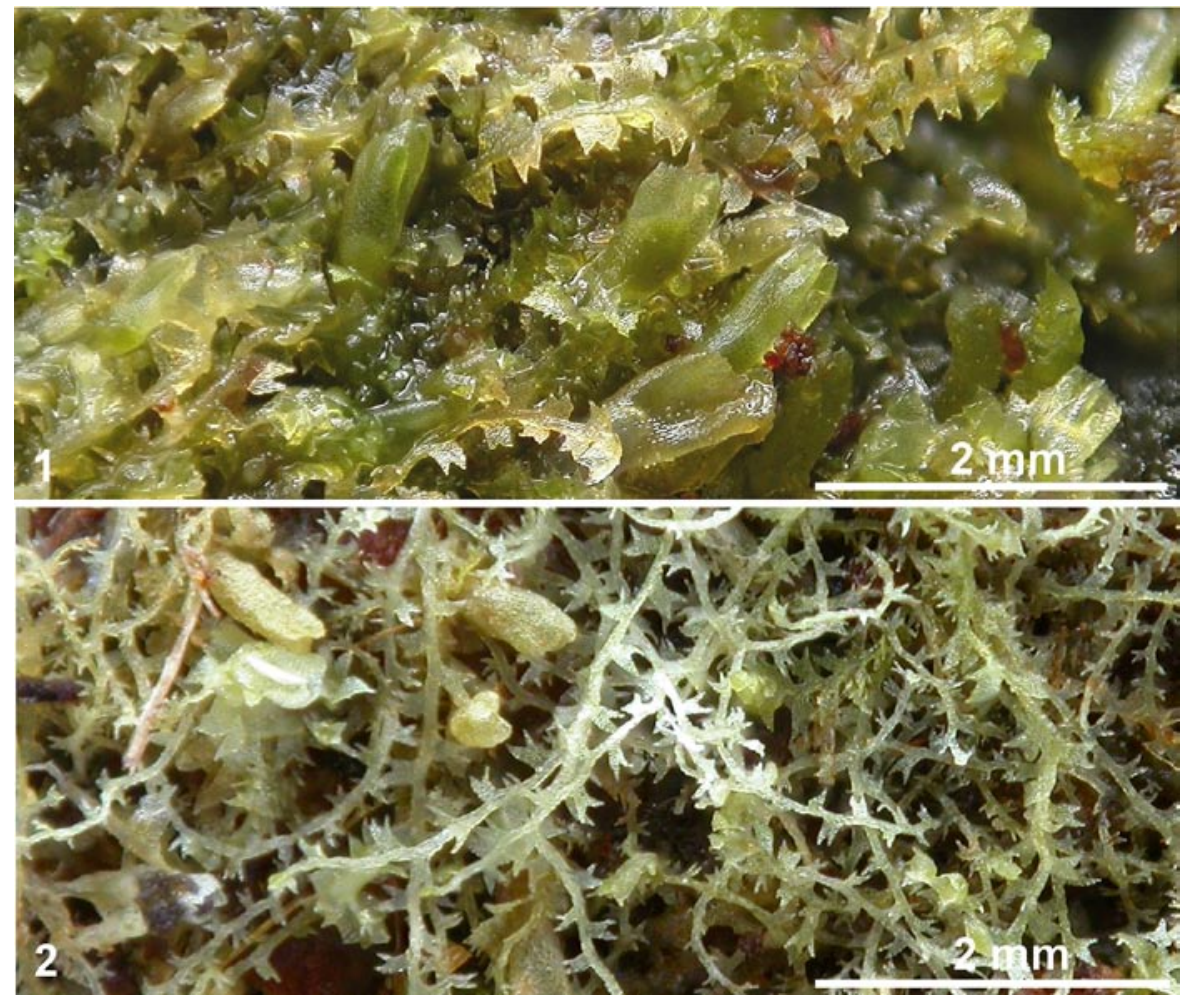

Fig. 4. 1 - Cylindrocolea sanctae-helenae M. Wigginton, sp. nov. (robust form), on rotting log. St. Helena: Wigginton 05/191 (holotype). 2 - Cylindrocolea sanctae-helenae (slender form), on leaf petiole of tree fern, Dicksonia arborescens. St. Helena: Wigginton 05/335.

3b, and 3c suggest that $C$. obtusifolia differs from the St. Helena taxon in its hardly decurrent leaf base, the ovate rather than rectangular leaf shape and the blunt leaf lobes. C. obtusifolia Fulford was treated as a synonym of $C$. rhizantha (Mont.) R. M. Schust. by Gradstein and Costa (2003), but Schuster (2002) considered that 'there is no affinity' between the two species.

Of the other described species of Cylindrocolea, the St. Helena taxon (especially the slender forms) appears to be closest in general appearance to $C$. gittinsii E. W. Jones, an apparently rare but doubtless overlooked species of the African mainland that is currently known only from single collections from Cameroon, Uganda and Kenya. The taxa are similar in size, and in the shape and antical decurrence of the leaves [Jones (1960) described the antical margin of the leaf of $C$. gittinsii to be slightly decurrent, but in the Uganda specimens examined the leaves of some shoots are strongly and broadly decurrent]. However, $C$. gittinsii differs from the St. Helena taxon in the oblong terminal cells of the perianth mouth (Fig. 5.1), the fusiform perianth that tapers above to a small mouth that is not laciniate-dentate, and perhaps also consistently by the connivent lobes of the female bracteole.

The other African species of Cylindrocolea (Jones 1960) are readily distinguished from the St. Helena taxon by the quadrate or shortly rectangular terminal cells of the perianth mouth (Fig. 5), and are further distinguished as follows: $C$. atroviridis (Sim) Váňa by its widely-flared perianth month, leaf shape and non-decurrent leaves; C. ugandica E. W. Jones by its obliquely inserted, \pm strongly channelled leaves, and its mammillose leaf cells; C. nigerica $\mathrm{E}$. W. Jones by its much greater size (leafy shoots to $1.2 \mathrm{~mm}$ wide) and $C$. chevalieri 
(Steph.) R. M. Schust. by its retuse or very shallowly lobed leaves. C. madagascariensis (Steph.) R. M. Schust. is, according to Schuster (1973), close to C. nigerica, and he considered that 'further study may show that they are not separable'. In addition, judging by the description and drawings, Cephaloziella abyssinica Gola (Gola 1914) seems likely to be a species of Cylindrocolea, its leaves obliquely inserted, and perianth having a wide mouth.

Of the other described species, $C$. rhizantha (Schuster 1980), C. acutiloba (Schiffn.) J. J. Engel (Schiffner \& Arnell 1964) (which is probably synonymous with $C$. rhizantha), and C. reticulata Udar \& D. Kumar (Udar \& Kumar 1982) are all differentiated by the wide, flaring, truncate perianth mouth, and the gynoecia always or nearly always borne terminally on long or leading axes; C. brasiliensis Costa, Santos \& Váňa (Costa

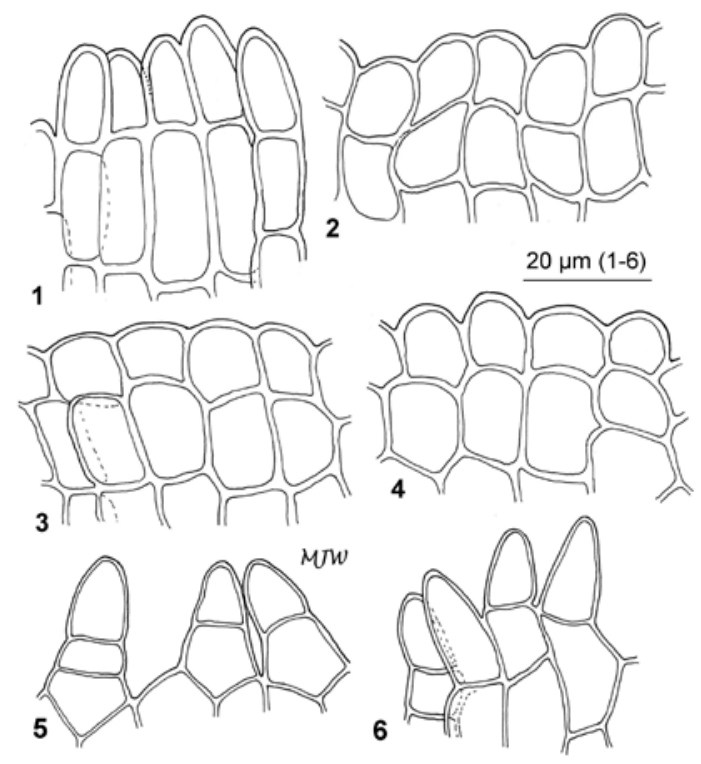

Fig. 5. Cells at perianth mouth. $1-$ Cylindrocolea gittinsii (E. W. Jones) R. M. Schust., Uganda, Gittins 7, 2 - Cylindrocolea nigerica (E. W. Jones) R. M. Schust., Nigeria, E. W.J ones 66, 3 - Cylindrocolea atrovirens (Sim) Váňa, Uganda, Hodgetts 4040a, 4-Cylindrocolea ugandica (E. W. Jones) R. M. Schust., Uganda, E.W.Jones 579, 5 - Cylindrocolea sanctae-helenae M. Wigginton, St. Helena, Wigginton 05/191 (holotype), 6 - Cylindrocolea sanctae-helenae, St. Helena, Wigginton $05 / 335$. et. al. 2008) from all other species in the genus by its dentate leaves; C. planifolia (Steph.) R. M. Schust. and C. sprucei R. M. Schust. (Schuster 1973; Fulford 1976) by the long and narrow terminal cells of the perianth mouth, 4-10 times as long as wide; $C$. recurvifolia (Steph.) Inoue (Inoue 1972) and C. tagawae (N. Kitag.) R. M. Schust. (Kitagawa 1969) by their small, shortly bilobed, rigid leaves, small incrassate leaf cells and the stem with a very wide dorsal 'leaf-free' zone 4-5 or more cells wide; $C$. andersonii R. M. Schust. (Schuster 1980) by its branching pattern and apparent doiecy, and C. novae-caledoniae (Grolle) R. M. Schust. (Grolle 1960 as C. planifolia Grolle; Schuster 1973) by its narrowly ovate leaves, narrowed to a non-decurrent base.

It should be noted that in the guide to the mosses and liverworts of St. Helena (Wigginton 2012) Cylindrocolea sanctae-helenae was described under the unpublished name Cylindrocolea helenae.

ACKNOWLEDGMENTS. The funding for the survey is gratefully acknowledged from the UK Government's Overseas Territories Environmental Programme. My thanks also to staff at the Department of Agriculture and Forestry Conservation \& Wildlife Section, St. Helena for permission to collect bryophytes in the Diana's Peak National Park; to Rebecca Cairns-Wicks and the St. Helena National Trust for logistical support and other help on the island. I am especially grateful to Jiř́ Váňa for his comments on the collections, and to David Long for the loan of collections of Cylindrocolea from the herbarium of the Royal Botanic Garden, Edinburgh (E).

\section{REFERENCES}

Ashmole P. \& Ashmole M. 2000. St. Helena and Ascension Island: a natural history. Anthony Nelson, Oswestry.

Costa D. P., SAntos N. D. \& VÁŇA J. 2008. A new species of Cylindrocolea (Cephaloziellaceae) from Brazil. Bryologist 111: 667-669.

FULFORD M. 1976. Manual of the leafy Hepaticae of Latin America. IV. Mem. New York Bot. Gard. 11(4): 393-535.

Gola G. 1914. Epatiche dell'Abissinia. Ann. Bot. (Rome) 13: 59-75.

Gradstein S. R. \& DA Costa D. P. 2003. The Hepaticae and Anthocerotae of Brazil. Mem. New York Bot. Gard. 87: xviii. 1-318. 
Grolle R. 1960. Nachtrag zur "Revision der ClasmatocoleaArten”. Rev. Bryol. Lichénol. 29: 68-91.

INOUE H. 1972. Miscellaneous notes on hepatics of Japan (7). J. Jap. Bot. 47: 347-350.

Jones E. W. 1960. African Hepatics XIV. Some Cephaloziellas of lowland Tropical Africa. Trans. Brit. Bryol. Soc. 3: $430-440$.

KitAgAWA N. 1969. Studies on the hepaticae of Thailand, II. Cephalozia and Cephaloziella. J. Hattori Bot. Lab. 32: 290-306.

SCHIFFner V. \& ARnell S. W. 1964. Ergebnisse der botanischen Expedition der kaiserlichen Akademie der Wissenschaften nach Südbrasilien, 1901. II. Band (Thallophyta und Bryophyta), Hepaticae. Österr. Akad. Wiss., Math.Naturwiss. Kl., Denkschr. 111: 1-156.

SCHUSTER R. M. ['1972'] 1973. Studies on Cephaloziellaceae. Nova Hedwigia 22: 122-265; 266a-c.
SCHUSTER R. M. 1980. The Hepaticae and Anthocerotae of North America. 4. Columbia University Press, New York.

SCHUSTER R. M. 2002. Austral Hepaticae, Part II. Nova Hedwigia Beih. 119: viii, 1-606.

UDAR R. \& KUMAR D. 1982. A remarkable Cylindrocolea Schust. from India. Lindbergia 8: 181-184.

Vital D. M. \& VISNADI S. R. 1994. Bryophytes of Rio Branco Municipality, Acre, Brazil. Trop. Bryol. 9: 69-74.

Wigginton M. J. 2006. Bryophytes of St. Helena, South Atlantic Ocean. 1. Three new species of Cololejeunea (Jungermanniales, Lejeuneaceae), C. dianae sp. nov., $C$. sanctae-helenae sp. nov. and C. grossestyla sp. nov. from St. Helena, South Atlantic Ocean. J. Bryol. 28: 363-373.

Wigginton M. J. 2012. Mosses and liverworts of St. Helena. Pisces Publications, Newbury.

\section{Received 20 February 2013}

\section{SPECIMENS EXAMINED}

The six-figure UTM grid references are taken from the 1:25000 O.S. map of St. Helena, edition 7-OSD 1990 (Ordnance Survey, U.K.). All the collections of Cylindrocolea sanctae-helenae made in 2005 are held at E, with a sub-set on St. Helena (location of herbarium not yet decided).

Cylindrocolea sanctae-helenae M. Wigginton, sp. nov.

ST. HELENA: Blue Hill Village, in small valley E of road: on shaded, moist upper surfaces of horizontal rotting tree trunk, in Podocarpus elongata-Agave community in valley bottom, $525 \mathrm{~m}$., 30L/TH/055314, $5^{\circ} 45^{\prime} \mathrm{W}, 15^{\circ} 58^{\prime} \mathrm{S}, 23$ Oct. 2005, Wigginton 05/191 (holotype); Blue Hill Village in small valley $\mathrm{E}$ of road: with Fissidens translucens on shaded low rock in valley bottom, $517 \mathrm{~m} ., 30 \mathrm{~L} / \mathrm{TH} / 054314,5^{\circ} 45^{\prime} \mathrm{W} 15^{\circ} 58^{\prime} \mathrm{S}$, 23 Oct. 2005, Wigginton 05/186A; Blue Hill Village in small valley $\mathrm{E}$. of road: on rotting tree stump in valley bottom, $517 \mathrm{~m}$., 30L/TH/054314, 54ㄴ $5^{\prime} \mathrm{W} 15^{\circ} 58^{\prime} \mathrm{S}$, 23 Oct. 2005, Wigginton 05/188C, 05/189A; St. Paul's, path to Boer Cemetery, on roots and loose loamy soil at base of earthy bank by path, in deep shade under trees, with Fissidens darntyi and Sematophyllum helenicum, 495 m., 30L/TH/087344, 543'W 1557'S, 6 Nov. 2005, Wigginton 05/469B, 05/470; Alarm Forest road, N of
Hutts Gate, on moist rock on roadside bank on $\mathrm{W}$ side of road, $620 \mathrm{~m} ., 30 \mathrm{~L} / \mathrm{TH} / 104341,5^{\circ} 42^{\prime} \mathrm{W} 15^{\circ} 57^{\prime} \mathrm{E}, 7 \mathrm{Nov}$. 2005, Wigginton 05/516; Diana's Peak National Park: with Tylimanthus anisodontus, on moist, deeply-shaded vertical rock wall under overhang, by stand of Sium bracteatum, 739 m., 30L/TH/105327, 12 Nov. 2005, Wigginton 05/615.

Cylindrocolea sanctae-helenae $\mathrm{M}$. Wigginton (slender form)

ST. HELENA: Diana's Peak National Park, near Cuckold's Peak, on rotting petioles and dead leaves of tree-fern Dicksonia arborescens, associated with Chiloscyphus coadunatus, Chiloscyphus humistratus, Kurzia nemoides, Riccardia sp. and Sematophyllum erythrocaulon in humid, deeply-shaded location on steep Wfacing slope, $785 \mathrm{~m}$., $30 \mathrm{~L} / \mathrm{TH} / 101328,5^{\circ} 42 \mathrm{~W} 15^{\circ} 58^{\prime} \mathrm{S}$, 31 Oct. 2005, Wigginton 05/335; Diana's Peak National Park, S. of Actaeon peak: with Chiloscyphus sp. on decaying petiole of tree-fern, Dicksonia arborescens in shaded and humid location near stream in deep valley, 750 m., 30L/TH/108322, $5^{\circ} 42^{\prime} \mathrm{W} 15^{\circ} 58^{\prime} \mathrm{S}, 9$ Nov. 2005 , Wigginton 05/551, 05/554.

\section{Cylindrocolea atroviridis (Sim) Váňa}

UGANDA: Bwindi Forest National Park: bark on fallen rotting tree, $2310 \mathrm{~m}$., $1^{\circ} 3^{\prime} \mathrm{S} 29^{\circ} 46^{\prime} \mathrm{E}, 26 \mathrm{Jan}$. 
1996, N. G. Hodgetts 4040a (E); Kibale National Park: on trunk of fallen tree, $1500 \mathrm{~m} ., 0^{\circ} 33^{\prime} \mathrm{N} 30^{\circ} 21^{\prime} \mathrm{E}, 24 \mathrm{Feb}$. 1996, Wigginton $5283 a$ (E); Budongo Forest Reserve: on rotting $\log$ on forest floor, $1076 \mathrm{~m} ., 1^{\circ} 43^{\prime} \mathrm{N} 31^{\circ} 31^{\prime} \mathrm{E}$, 21 Feb. 1996, Wigginton 8415 a (E).

Cylindrocolea gittinsii (E. W. Jones) R. M. Schust.

UGANDA: Murchison Falls: on damp rock detritus over base-rich metamorphic rocks in very deep shade on the Acholi (Gulu) bank of the Nile, $2400 \mathrm{ft}$. alt., $2^{\circ} 16^{\prime} \mathrm{N} 31^{\circ} 41^{\prime} \mathrm{E}, 11$ June 1956, R. Gittins 7 (E).

Cylindrocolea nigerica (E. W. Jones) R. M. Schust.

NIGERIA: Okomu Forest Reserve: on rotten fallen logs in deep shade, approx. $6^{\circ} 16^{\prime} \mathrm{N} 5^{\circ} 12^{\prime} \mathrm{E}$, Dec. 1957 , E. W. Jones 36 (E), E. W. Jones 66 (coll. P.W. Richards) (E).
Cylindrocolea ugandica (E. W. Jones) R. M. Schust.

UGANDA: Budongo Forest: on large rotting log in shade, $3500 \mathrm{ft}$., $1^{\circ} 43^{\prime} \mathrm{N} 31^{\circ} 31^{\prime} \mathrm{E}$, July 1955, E. W. Jones 538 (E); Mpigi, Mpanga Research Forest: on rotting logs lying on the ground, $0^{\circ} 12^{\prime} \mathrm{N} 32^{\circ} 18^{\prime} \mathrm{E}$, July-August 1955, E. W. Jones 579, 605 (E). 